Original Research Paper

\title{
Pengelolaan dan Penanggulangan Sampah di Desa Batuyang Kecamatan Pringgabaya Kabupaten Lombok Timur
}

\author{
Rusminah HS ${ }^{1}$, Rian Sri Gede ${ }^{1}$, Intan Islamiyah ${ }^{1}$, Ranggit Aditya ${ }^{1}$, Rimbun Ria Lestari ${ }^{1}$, M. Nur Ihsan ${ }^{1}$, \\ Eka Sulis Febrianti ${ }^{1}$ \\ ${ }^{1}$ Fakultas Ekonomi Dan Bisnis, Universitas Mataram, Indonesia
}

https://doi.org/10.29303/jpmpi.v3i2.910

Sitasi: Rusminah., Gede, R. S., Islamiyah, I., Aditya, R., Lestari, R. R., Ihsan, M. N., \& Febrianti, S. (2021). Pengelolaan dan Penanggulangan Sampah di Desa Batuyang Kecamatan Pringgabaya Kabupaten Lombok Timur. Jurnal Pengabdian Magister Pendidikan IPA, 4(3)

\section{Article history}

Received: 22 Juli 2021

Revised: 31 Juli 2020

Accepted: 1 September 2021

*Corresponding Author:

Rusminah, Fakultas Ekonomi

dan Bisnis, Universitas

Mataram, Indonesia

Email:

rosewahyu99@gmail.com

\section{Pendahuluan}

Kuliah Kerja Nyata atau yang lebih dikenal dengan KKN merupakan salah satu bentuk kegiatan yang telah diformulasikan oleh pihak Universitas dimana mahasiswa lintas keilmuan dan sektoral pada tempat dan waktu tertentu selama periode kuliah diwajibkan untuk turun ke lapangan dan melakukan pengabdian di dalam masyarakat.

\begin{abstract}
Permasalahan mengenai sampah merupakan hal lumrah yang terjadi disetiap sektor masyarakat, namun di dalam penanganannya sektor ini membutuhkan perhatian lebih besar serta ketelatenan dari berbagai pihak. Tidak hanya kesadaran masyarakat akan pentingnya pengelolaan dan pengolahan sampah serta inisiatif akan hal tersebut, pemerintah disisi lain harus mampu untuk menumbuhkan kesadaran tersebut di dalam masyarakat serta memberikan fasilitas yang mumpuni di dalam menjalankan progam yang berkenaan dengan hal tersebut. Ketiadaan Tempat Pembuangan Akhir (TPA) merupakan salah satu permasalahan krusial yang harus segera diselesaikan agar sampah-sampah dari masyarakat tidak menumpuk pada titik tertentu. Situasi ini kemudian selaras dengan kondisi lapangan pada Desa Batuyang yang berlokasi di Kecamatan Pringgabaya Kabupaten Lombok Timur. Ketiadaan TPA maupun Tempat Pembuangan Sampah Sementara (TPSS) kemudian mendorong warga untuk membuang sampah di sungai sebagai solusi praktis. Berangkat dari hal tersebut, kegiatan Kuliah Kerja Nyata (KKN) dengan tema Zero Waste kemudian dilakukan sebagai salah satu wujud peran mahasiswa dalam menangani permasalahan di lapangan. Adapula solusi yang dihasilkan diantaranya ialah menjalin kerjasama dengan TPA terdekat dengan melibatkan pemuda setempat dalam kegiatan pengangkutan sampah serta pengolahan sampah organic dan non-organik dengan luaran produk berupa kompos, hydroponik dan ecobrik.
\end{abstract}

Keywords: Pengelolaan Sampah, TPA, Zero Waste, Penanganan Sampah

Berbagai Universitas di Indonesia telah menetapkan kegiatan KKN sebagai salah satu mata kuliah yang harus dijalankan oleh mahasiswa, dimana salah satu Universitas yang menjalankan kegiatan tersebut ialah Universitas Mataram.

Dalam melaksanakan kegiatan KKN ini terdapat tema yang telah ditetapkan oleh pihak Universitas sebagai acuan dalam melaksanakan kegiatan KKN, khususnya KKN Tematik dimana tema tersebut ialah Kewirausahaan, Maha Desa, 
Zero Waste, Ketahanan Pangan, dan lain-lain. Salah satu tema baru yang diusung oleh Universitas Mataram di dalam pelaksanaan KKN Tematik pada Tahun 2021 ialah tema Zero Waste. Berangkat dari fakta dimana persoalan sampah merupakan salah satu permasalahan lingkungan yang selalu meningkat setiap tahunnya, khususnya pada provinsi Nusa Tenggara Barat (NTB) serta fakta krusial di lapangan terkait dengan penumpukan sampah yang masif di berbagai wilayah NTB. Seperti yang dikutip dalam harian Republika, total sampah sebanyak 2.695 atau $80 \%$ dari total sampah di NTB tidak terurus dengan baik. Volume sampah di 10 Kabupaten/Kota di NTB mencapai 3.388 ton dengan jumlah sampah yang dibuang per harinya mencapai 76 ton dimana sampah yang masuk ke tempat pembuangan akhir (TPA) sampah dengan jumlah 641,92 ton dengan total sampah yang sudah di daur ulang hanya 51,21 ton per hari.

Berdasarkan data Dinas Lingkungan Hidup dan Kehutanan NTB, diantara 10 Kabupaten/Kota, Lombok Timur sendiri tercatat sebagai pengelolaan sampah terbesar dengan produksi 801 ton sampah per hari dimana sekitar $98 \%$ lainnya tidak terkelola. Salah satu penyebab dari penumpukan sampah ini ialah dikarenakan kurangnya TPA yang mampu mengelola sekiranya $70 \%$ sampah masyarakat baik sampah organik maupun sampah non-organik dari masyarakat Lombok Timur. Salah satu wilayah di Lombok Timur yang kemudian sangat membutuhkan perhatian secara saksama di dalam penanganan terkait dengan penumpukan sampah ialah wilayah Pringgabaya, khususnya pada Desa Batuyang dan difokuskan kembali pada Dusun Batuyang Daya. Adanya sungai yang mengalir melewati dusun ini kemudian dimanfaatkan oleh warga sebagai media TPA dikarenakan ketiadaan TPA serta koordinasi maupun yang terjalin diantara pemerintah Desa dengan dinas kebersihan maupun TPA terdekat terkait dengan pengangkutan sampah menuju TPA tersebut.

Berdasarkan hal tersebut, penempatan mahasiswa KKN Tematik dari Universitas Mataram pada periode tahun 2021 di Desa Batuyang dengan tema Zero Waste kemudian membuktikan bahwa Universitas Mataram memperhatikan persoalan lingkungan dengan saksama, agar solusi terkait dengan permasalahan yang terjadi dapat terselesaikan secara efektif.

\section{Metode}

Kegiatan KKN ini dilakukan di desa Batuyang Kecamatan Pringgabaya Lombok Timur. Kegiatan ini diawali dengan survey lapangan, wawancara serta pengumpulan data menggunakan media literasi harian dan jurnal luring.

\section{Hasil dan Pembahasan}

\section{Penanganan Tumpukan Sampah}

Penanganan sampah di Desa Batuyang merupakan hal harus di prioritaskan guna mewujudkan lingkungan yang bersih dan terbebas dari sampah, namun kebiasaan masyarakat yang dalam kesehariannya menjadi permasalahan utama yang harus diatasi. Kebiasaan masyarakat yang terbiasa membuang sampah dapur di kali merupakan kegiatan rutin setiap sore hari masyarakat sekitar, hal ini diakibatkan oleh tidak adanya tempat sampah yang di sediakan oleh desa. Pemerintah desa memegang tanggung jawab penuh atas berbagai macam upaya untuk menjaga kebersihan lingkungan sebagai wujudn pemberian rasa aman terhadap masyarakat sekitar. Menurut Siti Sundari Rangkuti (2000:171) mengatakan bahwa hak atas lingkungan hidup yang baik dan sehat dilihat dari sudut pandang bentuk dan isisnya, diimbangi keharusan bagi pemerintah untuk mengarsikan kebijaksanaan dan melakukan tindakan yang mendorong di tingkatkannya upaya melestarikan lingkungan yang bebas sampah.

Berdasarkan permasalahan-permasalahan yang ada maka KKN Tematik UNRAM dengan tema zero waste menginisiasi penanganan sampah di Desa Batuyang dengan cara melakukan pengangkutan yang dilakukan sebanyak dua kali per-minggu. Dalam menjalankan kegiatan tersebut mahasiswa menjalin kerjasama dengan para pemuda dengan harapan agar kegiatan ini dilaksanakan dengan sekala kegiatan jangka panjang.

Pengangkutan ini bertujuan untuk mengurangi pembuangan sampah rumah tangga di area sungai, sehingga setiap hari rabu pada pukul 15:00 wita dan hari minggu pukul 07:00 wita masyarakat mengumpulkan sampahnya menggunakan karung beras yang sudah dibagikan dan diangkut secara berkala oleh pemuda. Sampah yang sudah dikumpulkan tersebut akan dibuang ke 
Tempat Pembuangan Akhir (TPA) yang ada di Dusun Bare Runtak.

Program kerja pertama yang dilakukan sebagai upaya penyelesaian persoalan sampah ini adalah dengan terlebih dahulu melakukan sosialisasi dan edukasi terhadap masyarakat tentang mekanisme program pengangkutan sekaligus memberikan edukasi secara mendalam terhadap dampak yang ditimbulkan akibat aktivitas pembuangan sampah di sungai. Kegiatan sosialisasi dan edukasi kepada warga masyarakat kemudian mendapat dukungan penuh oleh perangkat desa serta menumbuhkan antusias warga terhadap progam kerja yang akan berjalan.

Formulasi program pengangkutan sampah dengan menjadikan Dusun Batuyang Daya sebagai sampeling awal penerapan program kemudian berjalan dengan baik, berangkat dari hal tersebut diharapkan program pengangkutan sampah ini bisa diterapkan di dusun lainnya. Dengan diterapkannya regulasi baru bersamaan dengan pemerintah desa untuk mendorong penerapan sanksi sosial maupun hukum terhadap masyarakat yang membuang sampah sembarangan, hal ini dilakukan agar masyarakat juga bisa lebih disiplin dan peduli terhadap kebersihan lingkungan.

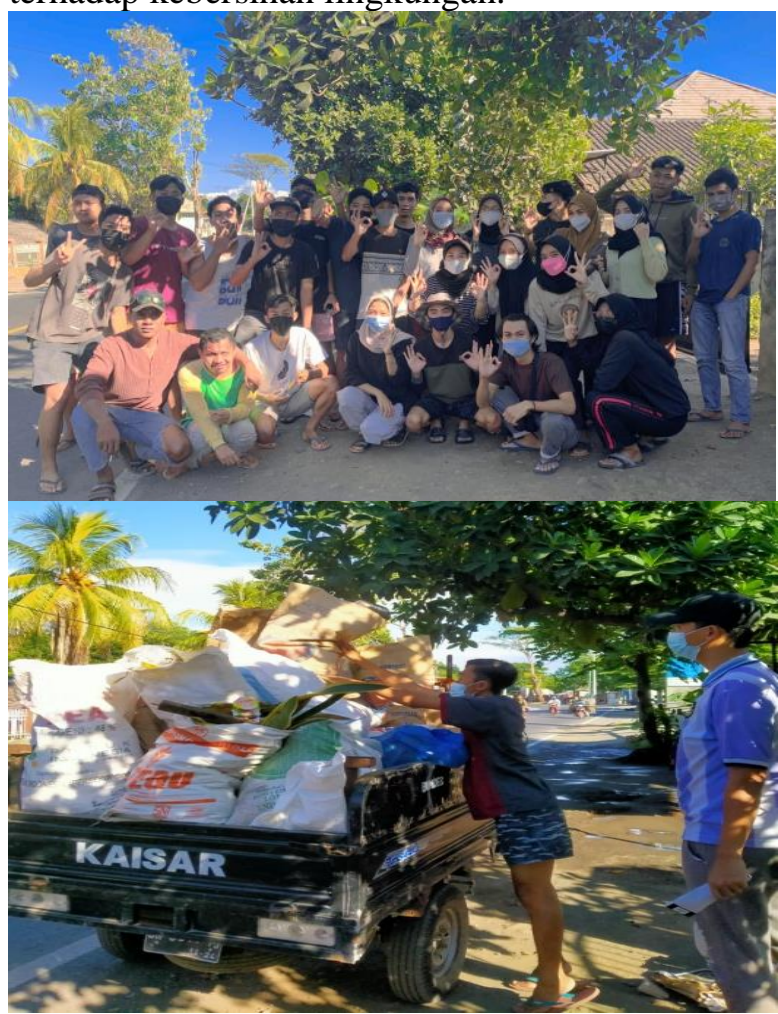

Gambar 1; Pengangkutan Sampah Menuju TPA.
Pengelolaan Sampah Organik Dan Non-Organik

Program kerja kedua yang ialah pengolahan sekaligus pemilahan terhadap sampah-sampah yang ada di masyarakat. Pengolahan jenis-jenis sampah di bagi menjadi 2 (dua) yaitu sampah organik dan non-organik hal ini dilakukan dengan tujuan mengubah persepsi masyarakat bahwa sampah yang ada di sekitar mereka bukan lah sesuatu hal yang tidak berguna namun dapat diolah kembali sesuai dengan manfaat yang di hasilkan. Hal-hal seperti ini perlu dilakukan guna mewujudkan desa yang bebas dari sampah. Adapun beberapa upaya yang dilakukan ialah sebagai berikut.

\section{Pembuatan Kompos Organik}

Kompos adalah hasil penguraian dari bahan organik yang kaya akan unsur Karbon dan Nitrogen. Kompos adalah salah satu dari berbagai macam pupuk organik. Kompos sangat bermanfaat untuk menetralkan $\mathrm{pH}$ tanah. Kompos menjadi salah satu solusi untuk menanggulangi sampah organik. Sampah organik berupa sampah rumah tangga, sampah dedaunan dan buah ataupun sayuran busuk. Pembuatan kompos oleh mahasiswa KKN Desa Batuyang didampingi oleh staff Asosiasi Bank Sampah Lombok Timur. Pembuatan kompos dimulai dari tahap persiapan yaitu mengumpulkan bahanbahan seperti kotoran ternak, dedak, abu sekam, gula, EM4, air dan sampah organik. Adapun peralatan yang diperlukan yaitu karung, ember, sarung tangan dan botol. Tahap selanjutnya yaitu mencampurkan semua bahan-bahan sampai bisa menjadi kepalan yang selanjutnya dimasukkan ke dalam karung dan ember untuk proses pembusukan atau pembentukan kompos. 


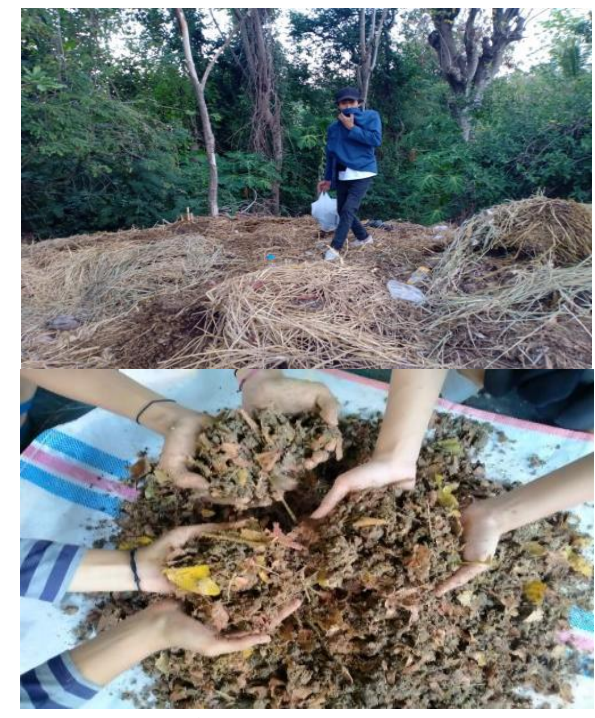

Gambar 1, Kompos.

\section{Pemanfaatan Botol Air Mineral sebagai Media Tanam Hydroponik}

Budidaya Hidroponik berasal dari kata yang diambil dari bahasa Yunani yaitu Hydro yang mempunyai arti air dan juga ponos yang mempunyai arti daya. Saat dua kata itu disatukan akan membentuk definisi budidaya suatu tanaman dengan memanfaatkan media air sebagai media tanam utamanya (soiless).

Budidaya Hidroponik merupakan salah satu cara pemanfaatan sampah plastic khususnya botol plastik yang mudah dan efisien. Budidaya Hidroponik dengan menggunakan botol plastic ini berguna untuk mengurangi penyebaran sampah botol plastic. Alat dan bahan yang digunakan untuk membuat budidaya hidroponik yaitu botol plastic, cutter, gunting, kain flannel, nutrisi, plastic hitam, bibit pakcoy, dan air.

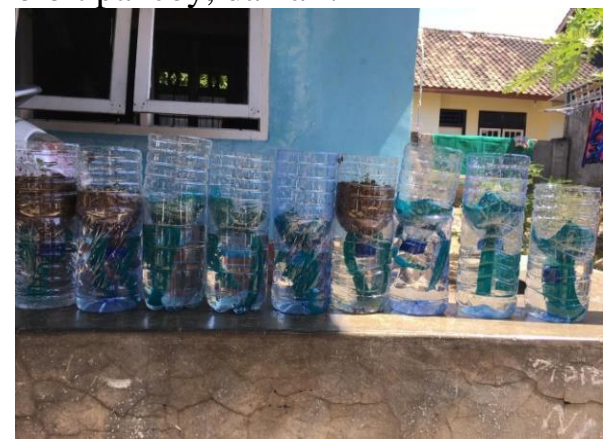

Gambar 2; Hydroponic.
Berikut adalah langkah-langkah dalam membuat budidaya dari botol plastik :

- Potong botol

Pertama potong bagian atas botol kira-kira 10 sentimeter dari ujung botol. Apabila dirasa masih terlalu besar atau tinggi, bisa disesuaikan.

- Buat lubang di ujung botol

Kedua, buatlah lubang di sisi kanan dan kiri pada bagian ujung botol yang sudah dipotong sepanjang dua sentimeter sebagai tempat memasukkan flannel.

- Masukkan flannel

Ketiga, masukkan kain flanel melalui lubang yang telah dibuat dari kiri ke kanan atau sebaliknya. Selanjutnya letakkan ujung botol dalam keadaan terbalik sebelum diisi air. Fungsi kain flanel ini ialah sebagai perantara menaikkan air ke akar tanaman.

- Tuangkan air

Keempat, tuangkan air nutrisi hidroponik ke botol bagian bawah atau kira-kira duapertiga dari tinggi botol.

- Letakkan tanaman

Kelima, masukkan tanaman pakcoy, atau lainnya yang sudah siap pindah tanam hingga bagian bawahnya menyentuh kain flanel.

- Tutup dengan plastik

Keenam, tutup bagian bawah botol menggunakan plastik hitam agar tidak tembus sinar matahari. Hal ini dilakukan agar tidak menyebabkan wadah berlumut.

- Perawatan

Perawatan tanaman hidroponik ini dilakukan untuk mengecek kebersihan air dan wadah secara berkala. Apabila wadah berlumut, perlu diganti dengan yang baru. Jika air dalam wadah habis, segera isi ulang dengan air yang baru. 


\section{Upaya Pengurangan Sampah Plastik dengan Teknik Ecobrik}

Ecobrik adalah sebuah botol plastik yang dikemas dengan memasukkan potongan plastik bekas dalam kondisi bersih dan kering dengan kepadatan tertentu yang digunakan untuk membuat suatu karya seni dan kreatifitas lainnya yang berdaya nilai tinggi. Ecobrick ini lebih difokuskan pada sampah plastik yang memiliki masa urai yang relatif lama dan membahayakan lingkungan seperti styrofoam, kabel, baterai, sampah-sampah plastik bekas makanan ringan dan lainnya. Namun sejauh ini upaya pengurangan sampah plastik dengan teknik ecobrik lebih difokuskan pada sampah-sampah plastik. Ecobrick sendiri dapat dimanfaatkan sebagai furniture (meja, kursi) ruang tanam, dinding bahkan suatu bangunan secara utuh (antico, wiener, araya-letelier dan gonzales retamal:2018).

Ecobrick merupakan metode yang digunakan untuk meminimalisir sampah plastik dengan media botol plastik yang diisi penuh dengan sampah anorganik. Kegiatan ecobrick yang dilakukan melibatkan adik-adik yang berada di dusun Batuyang Daya dan adik-adik TPQ Batuyang. Proses pembuatan ecobrick dimulai dengan pengumpulan sampah plastik yang selanjutnya dibersihkan dan dijemur. Setelah itu sampah yang sudah kering digunting dan dimasukkan ke dalam botol untuk melakukan pemadatan sampah dalam botol.

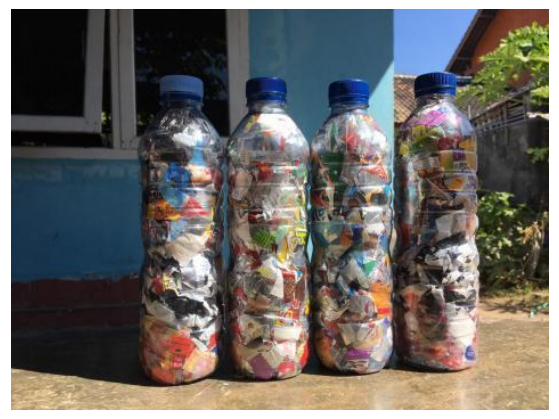

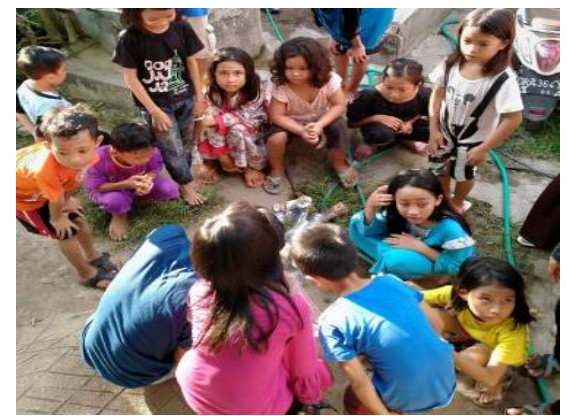

Gambar 2. Erobic

\section{Kesimpulan}

Kegiatan KKN yang berlangsung di Desa Batuyang dalam jangka waktu 45 hari kemudian tidak dapat dikatakan maksimal jika tidak melibatkan berbagai pihak di dalam pelaksanaan program kerja yang telah diusung. Ketiadaan Tempat Pembuangan Akhir (TPA) di Desa Batuyang sendiri kemudian menjadi salah satu tantangan yang harus segera di atasi oleh pemerintah desa, khususnya dengan menyediakan fasilitas tersebut. Tentu pengadaan fasilitas membutuhkan waktu, oleh karenanya mahasiswa KKN menawarkan berbagai solusi yang kemudian dapat diterapkan oleh pemerintah desa dalam menanganani serta mengolah sampah, mengingat sikap masyarakat desa yang kemudian memilih untuk menjadikan sungai sebagai TPA dengan berasaskan pemikiran praksis.

Dengan memberikan edukasi kepada masyarakat terkait dengan sampah, baik pengelolaan maupun pengolahannya diharapkan kedepannya masyarakat desa dapat memahami dengan saksama mengenai tindakan yang telah dilakukan. Selain solusi edukasi, mahasiswa yang bekerjasama dengan pihak desa serta para pemuda desa kemudian menjalankan program kerja pengangkutan sampah dimana dalam hal ini mahasiswa telah bekerjasama dengan TPA terdekat dari Desa Batuyang.

\section{Ucapan Trimakasih}

Ucapan trimakasi saya sampaikan kepada Bapak Kepala Desa dan seluruh staf dan masyrakat Desa Batuyang yangbtelah membanyak membantu dan mendukung kegiatan kami.

\section{Daftar Pustaka}


Siti sundari rangkuti. Hukum lingkungan dan kebijaksanaan lingkungan Nasional, Airlangga university press surabaya, 2015:edisi keempat.

Antico, F.C.,Wiener, M.J.,Araya-letelier,G,.\& Gonzales retamal,R. (2018). Eco-bricks ; a sustainable subtitute for construction materials.

Revista de la construction Ecobricks (2015). panduan visi ecobrik.

https://www.kompas.com/homey/read/2021/07/ 30/155650176/cara-membuat-wadahtanaman-hidroponik-dari-botolbekas?page=all\#page2. 